\title{
МЕХАНІЗМИ ЗАБЕЗПЕЧЕННЯ ПРАВ ДІТЕЙ В ІНФОРМАЦІЙНОМУ СЕРЕДОВИЩІ
}

\author{
НЕСТЕРЕНКО Анна Олександрівна - аспірант кафедри адміністративного \\ та інформаційного права, Навчально-науковий Інститут права, психології та \\ інноваційної освіти Національного університету «Львівська політехніка» \\ УДК 340.342.7.053.6(043.5) \\ DOI 10.32782/LAW.2020.3.11
}

Статья посвящена исследованию механизма обеспечения прав детей в информачионной среде. Отмечено, что под механизмом защиты прав и свобод человека и гражданина, необходимо понимать установленную и гарантированную законом систему обеспечения правового статуса личности, включающей упорядоченную деятельность органов публичной власти, негосударственнъгх правозащитнъгх организаций, самостоятельную реализаиию субъективньих прав и свобод, бункиионирование которых направлено на предупреждение, пресечение и восстановление нарушенных прав и свобод при соблюдении надлежащего баланса публичных и частнъхх интересов.

Ключевъе слова: права ребенка, механизм обеспечения прав ребенка, инбормачионная среда, ювенальная юстищия.

Постановка проблеми

Сучасний етап розвитку суспільства та держави найвищими цінностями проголошує права людини будь-якого віку. Історичне минуле, коли вперше питання про права людини були підняті на державному рівні, відноситься до XVIII століття. Проте, для виділення 3-поміж них прав дитини знадобилось ще два століття. Протягом тисячоліть діти розглядалися як майбутні члени суспільства. У міру становлення уявлень про самоцінність людської особистості в дітях стали бачити не тільки об'єкт виховного впливу, а й рівноправ- ного партнера суспільних відносин. Надбанням такого розуміння $є$ те, що дитина стала розглядатися як особистість, яка наділена гідністю, як дорослий з різницею в тому, що повнолітній може захищати свої інтереси самостійно, а дитина змушена звертатися за допомогою до тих, хто повинен забезпечувати її права. У цьому полягає специфіка механізму забезпечення прав дітей в інформаційному середовищі.

Аналіз дослідження проблеми

Забезпечення прав дітей, у тому числі в інформаційному середовищі досліджували вчені: А. Блага, Н. Бортник,В. Брижик, А. Волощук, В. Галунько,Б. Головкін, Т. Журавель, В. Копєйчиков,О . К о ч ᄉ. Крижна, К. Левченко,Н. Аесько, Ю. Аисюк, О. Мартиненко, П. Рабінович, Ю. Приколотіна, Н. Ортинська, Г. Христова, Х. Ярмакі, М. Ясеновська та інші. Розвиток теоретичних уявлень про права та свободи людини, а також інформаційного суспільства ставить перед науковою спільнотою та практикуючими правознавцями питання щодо прав дитини, які підлягають аналізу.

Метою статті $є$ дослідження механізму забезпечення прав дітей в інформаційному середовищі. 


\section{$=$ Адміністративне право}

Виклад основного матеріалу

Інформаційні права належать до молодого покоління прав людини. Вплив трансформаційних процесів соціуму вказує на важливу роль інформаційних прав для реалізації та захисту правового статусу людини.

У цьому контексті Н. Ортинська зазначає, що право на доступ до інформації має для неповнолітнього свої особливості, оскільки, враховуючи його моральну незрілість, правова політика держави повинна бути спрямована на обмеження отримання неповнолітнім інформації, яка негативно впливатиме на емоційний чи фізичний стан. Проте якщо йдеться про неповнолітню особу, інформаційні права мають особливості забезпечення та реалізації. Інформаційні права неповнолітніх $\epsilon$ ефективною формою соціалізації у демократичному суспільстві, показником активної громадянської позиції підростаючого покоління і своєрідним показником розвитку особистості. Европейська конвенція про здійснення прав дітей визнає, що дітям для підтримки прав та найвищих інтересів має надаватися відповідна інформація та, що думкам дитини має приділятися належна увага [1, с. 170-171].

Перш ніж з'ясувати юридичну природу механізму забезпечення прав дітей в інформаційному середовищі зокрема, звернемося до аналізу механізму захисту прав людини взагалі, де цей термін у різних авторів отримав різне тлумачення.

Державно-правовий механізм охорони основних прав і свобод громадян - це система конституційно-правових норм, структура державних органів, різноманітні політико-правові, соціально-економічні та соціально-психологічні чинники, форми та методи, способи, умови, засоби здійснення правових норм щодо встановлених процедур і принципів [2, с. 1012].

Механізм захисту суб'єктивного права і законних інтересів, на нашу думку, - це взята в єдності система правових засобів, за допомогою якої забезпечується відновлення порушених суб'єктивних прав, захист охоронюваних законом інтересів, вирішення правових спорів і усунення інших перешкод в реалізації суб'єктивних прав. Механізм соціально-юридичного захисту прав людини - це певна система засобів і чинників, що забезпечують необхідні умови поваги до всіх прав і основних свобод людини, що випливають із гідності, властивої людській особистості, є суттєвими для вільного та повного розвитку. Головна мета функціонування механізму - це захист суб’єктивних прав людини та громадянина.

Як зазначає Н. Опольська, підхід щодо механізму дає змогу розглянути забезпечення прав та свобод людини у двох вимірах: статичному та динамічному. Досліджуючи це поняття як статичне явище, можна охарактеризувати його структуру, сукупність складових елементів [3, с. 194].

До завдань механізму входить охорона, захист, відновлення порушених прав, формування загальної та правової культури населення. Однак, аналізована юридична категорія потребує узагальнення i уточнення. На нашу думку, під механізмом захисту прав і свобод людини та громадянина необхідно розуміти встановлену та гарантовану законом систему забезпечення правового статусу особи, що включає впорядковану діяльність органів публічної влади, недержавних правозахисних організацій, самостійну реалізацію суб'єктивних прав і свобод, функціонування яких спрямоване на попередження, припинення та відновлення порушених прав і свобод при дотриманні належного балансу публічних і приватних інтересів.

Що стосується механізму забезпечення прав дітей в інформаційному середовищі, то в цьому випадку, з погляду на дослідження Н. Аесько, «адміністративно-правове забезпечення формування та реалізації державної політики у сфері захисту дітей від насильства та інших протиправних дій», - правозахисний механізм неповнолітніх - це система взаємодіючих соціальних і правових засобів, що застосовуються для забезпечення прав [4]. 
У цьому випадку автор акцентує увагу на системі засобів соціального та правового забезпечення прав дитини. Під соціальним забезпеченням слід розуміти систему економічних, організаційних, правових заходів, які гарантуються державою та забезпечують неповнолітнім громадянам умови для подолання важких життевих ситуації. Поняття правового захисту трактується як забезпечення прав і законних інтересів юридичними засобами.

Варто зазначити, що дефініція «соціальне забезпечення» набагато ширше поняття «правове забезпечення», оскільки останне входить у категорію першого, виходячи з того, що юридичні засоби - частина соціальної системи регулювання та впливу на суспільні відносини, в тому числі у питаннях забезпечення прав, охорони та захисту особи [5].

Спеціальний механізм забезпечення прав дітей, у тому числі в інформаційному середовищі, в Україні, включає напрями:

- заходи забезпечення прав дітей в інформаційному середовищі при здійсненні діяльності у галузі освіти та виховання, що реалізуються шляхом створення 3 ініціативи неповнолітніх громадських об'єднань (організацій) за місцем навчання; проведення дисциплінарного розслідування діяльності працівників закладів освіти, які порушують і обмежують права неповнолітніх учнів, проведення в позаурочний час зборів з питань захисту прав;

- забезпечення прав неповнолітніх на охорону здоров'я, які здійснюють через надання дітям безкоштовної медичної допомоги та медичної діагностики, проведення лікувально-оздоровчої роботи,у тому числі диспансерного спостереження, медичної реабілітації дітей-інвалідів та дітей, які страждають хронічними захворюваннями, санаторно-курортне лікування дітей, профілактичні заходи щодо позбавлення ігрової та Інтернет залежності;

- захист прав і законних інтересів неповнолітніх громадян у сфері професійної орієнтації, професійної підготовки та за- йнятості. Такий вид передбачає заходи, пов'язані із забезпеченням професійної орієнтації, професійної підготовки дітей, які досягли 14-ти річного віку. У разі прийому на роботу дітей, які досягли 15-ти річного віку, їм гарантують винагороду за працю, охорону праці, скорочений робочий день, відпустка, а працівникам молодше 18-ти років надаються пільги при поєднанні роботи з навчанням, проведення щорічного обов'язкового медичного огляду тощо;

- захист прав дітей на відпочинок i оздоровлення, що реалізується через збереження та розвиток установ, діяльність яких спрямована на відпочинок і оздоровлення дітей;

- захист прав і законних інтересів дитини при формуванні соціальної інфраструктури для дітей, у тому числі інформаційної, що здійснюється за допомогою експертної оцінки і обліку нормативів будівництва об’єктів соціальної інфраструктури для дітей, використання цих об'єктів тільки за прямим призначенням;

- захист дитини від інформації, пропаганди та агітації, що завдають шкоди здоров'ю, моральному та духовному розвитку, що реалізується шляхом вжиття заходів, у тому числі захисту від національної, соціальної нетерпимості, від реклами алкогольної продукції та тютюнових виробів, від пропаганди соціальної, расової, національної та релігійної нерівності, від поширення друкованої продукції, аудіота відеопродукції, що пропагує насильство та жорстокість, порнографію, наркоманію, токсикоманію, антигромадську поведінку [4, с. 270];

- захист прав дітей, які перебувають у важкій життєвій ситуації, яка здійснюється шляхом соціальної реабілітації, судового захисту прав, позасудових процедур 3 урахуванням забезпечення пріоритету особистого та соціального благополуччя дитини, особливостей віку та соціального стану неповнолітнього.

На думку Т. Перуна, механізм є категорією теорії права, яка повинна відобража- 


\section{Адміністративне право}

ти момент «руху правової форми», спосіб iii функціонування і систему юридичних засобів впливу, які в сукупності складають правове регулювання [5, с. 90].

Конструкція механізму забезпечення прав дітей в інформаційному середовищі включає: нормативну визначеність (закріплення в нормативно-правовому акті); органи (систему органів) публічної влади, наділені функціями забезпечення прав дітей в інформаційному середовищі; систему показників, звітності та централізованого збору інформації, що відображає стан практики адміністративно-правового забезпечення прав дітей в інформаційному середовищі; спеціальні заходи адміністративно-правового забезпечення прав дітей в інформаційному середовищі; наявність норм, що передбачають юридичну відповідальність за посягання на охоронювані відносини; інші заходи забезпечення прав дітей в інформаційному середовищі, пов’язані з соціальною адаптацією; спрямовані на інформування про негативні наслідки (правові, медичні, соціальні тощо), антисоціальні явища; спрямовані на зміцнення та захист інституту сім'ї; заборона пропаганди та реклами антисоціальних явищ; взаємодія органів виконавчої влади 3 громадськістю (в тому числі волонтерськими організаціями); спеціалізовану соціальну допомогу; психологічне забезпечення прав дітей в інформаційному середовищі; духовне (релігійне) забезпечення прав дітей в інформаційному середовищі.

Стосовно об'єктів забезпечення вчені виділяють різні ознаки. Об'єкт забезпечення повинен володіти такими ознаками: реально існувати незалежно від волі та свідомості громадян, становити для особи, суспільства та держави певну цінність, благо; відчувати потребу в охороні, бути захищеним від протиправних та інших дій, погроз будь-якого характеру; на нього поширюється суверенітет держави, його забезпечення $\epsilon$ внутрішньою справою держави; він повинен знаходитися у взаємодії з суб'єктом забезпечення і охорони, який встановлює правовий режим; повинен передбачатися нормами права; забезпечення права повинно носити предметний характер [6, с. 247-248].

Забезпечення прав дітей в інформаційному середовищі як об'єкт має на увазі наявність соціальних благ, визнаних державою та захищених органами публічної влади, за посягання на які передбачається можливість застосування заходів державного захисту. Характеризуючи елементи конструкції адміністративно-правового забезпечення прав дітей в інформаційному середовищі, необхідно підкреслити, що одним 3 них 6 нормативна визначеність. Базові, вихідні положення закріплюються в основних законах держав, що дозволяє спочатку вважати права дітей в інформаційному середовищі об'єктом конституційно-правового захисту.

У конституціях, передусім, знаходять відображення відносини, пов'язані з правами громадян, їх забезпеченням. Відносини встановлені на конституційному рівні орієнтовані на морально-етичні установки суспільства і одночасно визначають вектор його розвитку. Можна запропонувати таку градацію груп норм, що регламентують забезпечення прав дітей в інформаційному середовищі, відповідно цільової спрямованості та функціям.

Групи норм, у яких права дітей системно вказується як мета забезпечення поряд 3 іншими базовими для держави об'єктами захисту, такими як основи конституційного ладу, здоров'я, права та законні інтереси інших осіб, забезпечення оборони країни та безпеки держави.

Групи норм, у яких права дітей закріплюються як єдиний родовий об'єкт посягання при вчиненні злочинів і адміністративних правопорушень. Конкретні різновиди посягань виражають об'єктивну сторону правопорушень, відповідні суспільні відносини охороняють санкції.

Групи норм, спрямовані на захист моральності неповнолітніх. Відповідно до Закону України «Про охорону дитинства» до повноважень органів державної влади України на здійснення гарантій прав 
дитини відноситься вибір пріоритетних напрямів діяльності щодо забезпечення прав і законних інтересів дитини, охорони здоров'я та моральності визначеної Законом України «Про захист суспільної моралі» $[7 ; 8]$.

У вказаних законах сформульовано поняття інформаційної безпеки дітей; конкретизовані види інформації, що завдає шкоди здоров'ю та розвитку дітей; викладено порядок класифікації інформаційної продукції; визначені державні органи та громадські об'єднання, уповноважені здійснювати нагляд і контроль за дотриманням цього законодавства; встановлені вимоги для експертів, які здійснюють проведення експертизи інформаційної продукції.

Групи норм, що передбачають обмеження в професійній діяльності у зв'язку з наявністю судимості за вчинення злочинів проти суспільної моралі. Кодекс законів про працю України містить заборону на допуск до педагогічної діяльності осіб, які мають або мали судимість або піддавалися кримінальному переслідуванню.

У реалізації розглянутого механізму забезпечення прав дітей, у тому числі в інформаційному середовищі, існує низка проблем, які заслуговують уваги в контексті нашого дослідження.

Перша проблема полягає в тому, що, незважаючи на значний масив нормативних актів, так чи інакше пов'язаних з регулюванням прав дитини, спеціалізоване законодавство, що стосується неповнолітніх, не дає повного або вичерпного переліку державних органів і установ, які здійснюють державну політику в інтересах дітей, не є можливим визначити суб'єктів, відповідальних за соціально-правове становище неповнолітніх в Україні.

Друга проблема полягає у відсутності взаємодії органів держави, покликаних забезпечувати права дитини. Хоча, в реальності, така взаємодія має відбуватися при співпраці органів управління соціальним захистом населення, органів управління освітою, органів опіки та піклування, органів у справах молоді, органів управління охороною здоров'я, органів служби зайнятості, Національної поліції, інститутами Уповноваженого Президента з прав дитини, Уповноваженого Верховної ради України з прав людини.

Однак, на жаль, доводиться констатувати, що всі ці ланки державного апарату та місцевого самоврядування нині не вдається з'єднати в один ланцюжок, розподілити між ними компетенцію за гілками та рівнями влади, виключивши одночасно дублювання та паралелізм у роботі.

Водночас, можна сформулювати й третю проблему, що створює труднощі для ефективності дії правового захисту прав дитини. Немає єдиної системи, орієнтованої тільки на вирішення проблеми захисту прав дитини. Сьогодні захист прав неповнолітніх громадян в Україні реалізується різними суб'єктами в різних формах, на різних щаблях і рівнях захисту (міжнародному, державному, регіональному, місцевому).

Окреслене коло проблем у галузі забезпечення прав дітей в інформаційному середовищі в Україні далеко не вичерпане та може бути продовжене. Проте, перераховані вище проблеми дозволяють констатувати той факт, що в Україні нині назріла необхідність вдосконалення правового механізму забезпечення прав дітей в інформаційному середовищі.

Тому в цьому контексті слід звернутися до позитивного зарубіжного досвіду в окресленій галузі, де в різних країнах існують спеціальні механізми захисту інтересів дітей. Одним з інструментів захисту прав дитини в низці зарубіжних країн (СIIA, Канаді, Великій Британії, Бельгії, Франції, Польщі та інших країнах Европейського Союзу) $є$ формування особливого порядку судочинства щодо неповнолітніх, які вчинили протиправні дії - ювенальна юстиція, що є особливою системою правосуддя для неповнолітніх.

Основною доктриною цієї системи є те, що держава виступає як піклувальник або відповідальна особа за неповнолітніх, 


\section{Адміністративне право}

захищаючи їх від небезпечної поведінки i шкідливого оточення. Нині ювенальні суди діють більше ніж у 60 країнах світу.

Функцію захисту дітей від сімейного насильства у багатьох країнах Європейського Союзу виконують правоохоронні органи у співпраці з органами опіки, піклування, місцевого самоврядування та фахівцями 3 соціальної роботи. У них є досвід постійної та повсякденної роботи 3 сім'ями, які потрапляють в скрутне і навіть небезпечне становище. Соціальний працівник має законне право висунути до винних суворі вимоги.

У Німеччині, Голландії, Великобританії фахівці із соціальної роботи наділені широкими повноваженнями (щодо порушення кримінального провадження та клопотання про позбавлення батьківських прав).

Однак ідея створення ювенальних судів на практиці носить суперечливий характер. У колах ділової громадськості та 3-поміж населення розгораються дискуciï та суперечки 3 цього питання. Формування дієвого правозахисного механізму неповнолітніх в Україні передбачає тривалий процес, де кінцева мета повинна припускати створення такої ювенальної системи забезпечення прав дітей, у тому числі в інформаційному середовищі, яка відповідає міжнародним стандартам.

Законодавець, встановлюючи об'єкт механізму забезпечення прав дітей в інформаційній сфері, виходить із широти цього поняття, включає різні елементи, у тому числі ювенальну юстицію.

\section{Висновки}

Отже, узагальнюючи викладене вище, можемо зробити висновок, що забезпечення прав дітей в інформаційному середовищі як об'єкт правового захисту охоплює сукупність соціальних благ, визнаних державою, які захищаються органами публічної влади, загроза яким тягне можливість застосування заходів державного примусу. Система забезпечення прав дітей в інформаційному середовищі складається 3 різнорідних суб'єктів, уповноважених застосовувати заходи, спрямовані на забезпечення умов морального і духовного благополуччя дітей, заходи психічного примусу, адміністративної відповідальності, які реалізуються через адміністративноправовий механізм забезпечення. Необхідними умовами ефективного механізму забезпечення прав дітей в інформаційному середовищі є закріплення в Конституції України, попередження та мінімізації загроз. Конституційна вимога про гарантії забезпечення прав дітей, у тому числі в інформаційному середовищі прямо сформульована в нормах Закону України «Про захист дитинства». Проведений аналіз дає підстави стверджувати, що законодавець, встановлюючи права людини в інформаційному середовищі як об'єкт правового захисту, виходить із широти цього поняття. Ця обставина є суттєвою підставою реалізації потенціалу застосування відповідного адміністративно-правового механізму забезпечення прав дітей в інформаційному середовищі, але у межах обмежень, встановлених чинним законодавством.

\section{Лiтература}

1. Ортинська Н. В. Правовий статус неповнолітніх: теоретико-правове дослідження: дис. ... д-ра юрид. наук: 12.00.01. Аьвів, 2017. 524 с.

2. Єсімов С., Ковалів М., Скриньковський Р., Сопільник Р. Гарантії прав людини та громадянина при забезпеченні інформаційної безпеки. Traektoriâ Nauki= Path of Science. 2018. Vol. 4. № 5. S. 10081016.

3. Опольська Н. Механізм забезпечення прав та свобод людини у динамічному вимір. Підприємниитво, господарство і право. 2019. № 4. С. 191-195.

4. Аесько Н. В. Адміністративно-правове забезпечення формування та реалізації державної політики у сфері захисту дітей від насильства та інших протиправних дій: дис. ... д-ра юрид. наук: 12.00.07. Аьвів, 2019. 489 с. 


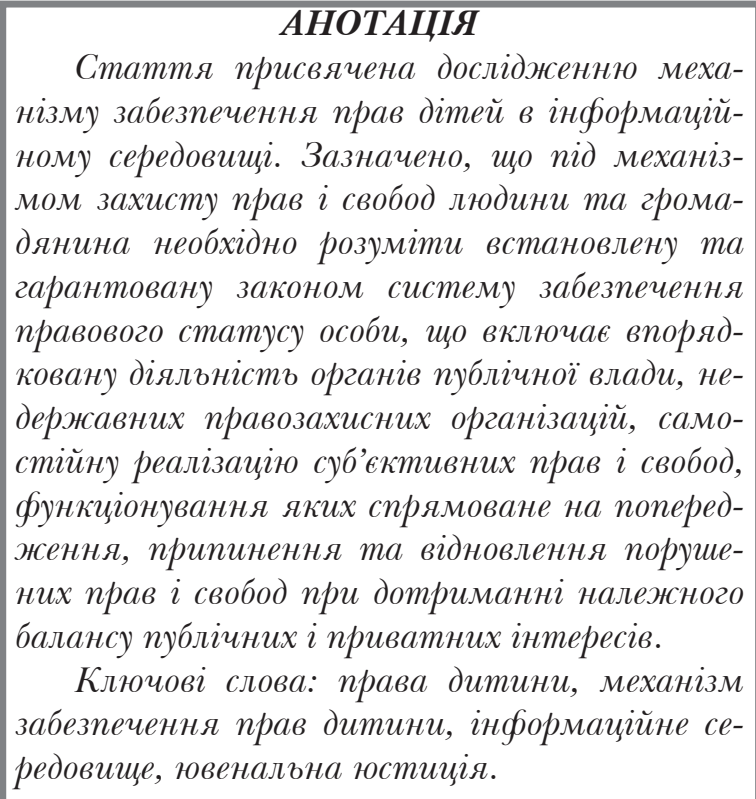

5. Перун Т. С. Адміністративно-правовий механізм забезпечення інформаційної безпеки в Україні: дис. ... канд. юрид. наук: 12.00.07. Аьвів, 2019. 268 с.

6. Ковалів М. В., Єсімов С. С., Аозинський Ю. Р. Правове регулювання правоохоронної діяльності: навчальний посібник. Аьвів: ЛьвДУВС, 2018. 323 с.

7. Про охорону дитинства: Закон України від 26.04.2001 р. № 2402-III. Відомості Верховної Ради України. 2001. № 30. Ст. 142.

8. Про захист суспільної моралі: Закон України від 20.11.2003 р. № 1296-IV. Відомості Верховної Ради Украӥни. 2004. № 14. Cт. 192.

\section{SUMMARY}

The article is devoted to the study of the mechanism of ensuring the rights of children in the information environment. It is noted that the mechanism of protection of human and civil rights and freedoms should be understood as a system of legal status of a person established and guaranteed by law, which includes orderly activities of public authorities, non-governmental human rights organizations, independent realization of subjective rights and freedoms. prevention, termination and restoration of violated rights and freedoms while maintaining the proper balance of public and private interests.

It is established that the design of the mechanism for ensuring the rights of children in the information environment includes: regulatory certainty (enshrined in the legal act); bodies (system of bodies) of public power, endowed with the functions of ensuring the rights of children in the information environment; a system of indicators, reporting and centralized collection of information that reflects the state of practice of administrative and legal support of children's rights in the information environment; special measures of administrative and legal support of children's rights in the information environment; the existence of norms that provide for legal liability for encroachment on protected relations; other measures to ensure the rights of children in the information environment related to social adaptation; aimed at informing about the negative consequences (legal, medical, social, etc.), antisocial phenomena; aimed at strengthening and protecting the family; ban on propaganda and advertising of antisocial phenomena; interaction of executive bodies with the public (including volunteer organizations); specialized social assistance; psychological support of children's rights in the information environment; spiritual (religious) provision of children's rights in the information environment.

The gradation of groups of norms regulating the provision of children's rights in the information environment, according to the target orientation and functions, is proposed. It was emphasized that the formation of an effective human rights mechanism for minors in Ukraine involves a long process, where the ultimate goal should be the creation of such a juvenile system for children's rights, in particular in the information environment that meets international standards.

Key words: children's rights, mechanism for ensuring children's rights, information environment, juvenile justice. 